\title{
The Chronology of the hillforts of Western Alania according to historical, archive and archaeological materials
}

\author{
Julia Treyman ${ }^{1, *}$ \\ ${ }^{1}$ Don state technical university, 344002, Rostov-on-Don, Russia
}

\begin{abstract}
The article is dedicated to revealing historic stages of the development of medieval architecture of Western Alania; systematization of the existing scientific materials connected with the dating of the medieval architectonic and archaeologic legacy of the region; revealing the periodization with defining corresponding cultural and ethnical peculiarities of architecture, compositional patterns and marking the influence of cultural borrowings. During the conducted research we revealed three chronological periods of the development of the architecture of the North Caucasus. At the first stage in the VI-VII c. A. D. appear the first Alan settlements along the western Caucasian part of the Great Silk Way. At the second stage in the VII- first half of the X c. fortifications are built in hillforts; also at this period was formed the three-part planning schemed which followed the principle: a citadel, a fortress, a fortified settlement. At the third stage in the X-XII c. the development of hillfort is performed under the influence of Byzantine Christian topographic traditions.
\end{abstract}

\section{Introduction}

The problem of studying Western Alan medieval hillforts, which are unique historical and cultural legacy of Karachay-Cherkessia, is connected to the study of historical origins of individuality and interaction of regional cultures of the Russian Federation.

The interest in the Alan culture and other antiquities of the North Caucasus appeared at the end of the XVIII c. In the XIX c. researchers' attention was concentrated mainly on Christian antiquities. Starting in 1846 the research was conducted by the Russian Archaeological Society. In 1864 appeared the Moscow Archaeological society founded by A. S. Uvarov. Its members P. S. Uvarova, V. F. Miller, V. M. Sysoev, D. M. Strukov, G. I. Kulikovskiy organized a number of expeditions to the North Caucasus and made several publications based on their results.

During the XX c. there were numerous archaeological researches of the North Caucasus headed by A. N. Dyachkov-Tarasov, V. F. Smolin, P. N. Shishkin, K. M. Petrelevich, T. M. Minaeva, E. G. Pchelina, A. N. Runich, L. N. Glushkov, A. L. Nechitaylo, E. P. Alekseeva, P. G. Akritas, E. I. Krupnov, O. V. Miloradovich, V. A. Kuznetsov, E. P. Alekseeva, Y. A. Fedorov, G. E. Afanasiev, I. M. Miziev, A. V. Naydenko, H. H. Bidzhiev,

\footnotetext{
*Corresponding author: treyman-17@yandex.ru
} 
A. V. Gadlo, G. H.-U. Tekeev, V. B. Kovalevskaya, V. I. Markovin, I. S. Kamenetskiy, E. I. Savchenko, V. N. Kaminskiy, I. V. Kaminskaya, E. A. Milovanov, U. Y. Elkanov, M. P. Abramova, S. N. Korenevskiy, I. A. Arzhantseva and others. These researchers collected vast factual material and justified the dating of hillforts on the basis of the analysis of the fragments of material culture discovered during the excavations. Nowadays archaeological works in the territory of the medieval north Caucasian monuments are performed by the expeditions of the Archaeological Institute of RAS.

The work on systematization and generalization of the historic and archaeological legacy of Karachay- Cherkessia is described in monographies by E. P. Alekseeva and H. H. Bidzhiev. In his works H. H. Bidzhiev studies the medieval monuments of KarachayCherkessia from the point of view of interaction and interpenetration of the cultures of the Turkic people of the North Caucasus [1]. After analyzing vast archaeologic material, V. A. Kuznetsov revealed three local variants of the Alan culture (western, central and eastern) in the territory of the North Caucasus. [2] V. A. Kuznetsov conducted further detailed analysis of historical facts from the history of the Alans' Christianization, revealed the groups of monuments of the medieval North Caucasian art of building according to the spheres of influence of Christian states (Byzantine in Western Alania, Georgian in Eastern Alania). [3]. The general picture of architecture of the North Caucasus according the stages of territorial and spatial exploration of the region is presented in the works by G. V. Esaulov. [4] During the research of Humarinskoe hillfort situated in Western Alania M. S. Gadzhiev drew an architectonic parallel with the fortresses from Sasanian Iran (the VI c.) and raised the problem of dating the fortifications in hillforts. [5] There are no generalized researches dedicated to revealing the stages of development of the hillforts in the medieval Alania (Western local variant of the Alan culture).

The goal of the research is the reconstruction of the historical stages of development of the medieval architecture in Western Alania, situated in the north of the Byzantine oecumene. The objective of the research: systematization of the existing material dedicated to the dating of medieval architectonic and archaeological legacy of the region: revealing the periodization and defining corresponding ethnical and cultural regularities, compositional patterns and marking the influence of cultural borrowings.

\section{Discussion and results}

In the territory of Karachay-Cherkessia there are about 70 preserved medieval hillforts. Wide-scale archaeological researches were conducted in Nizhne-Arkhyzskoe, LesoKyafarskoe, Humarinskoe, Karakentskoe, Indzhur-Gatinskoe, Pervomaiskoe, Adiuhskoe, Gilyachskoe, Amgatinskoe hillforts.

Nizhne-Arkhyzskoe hillfort is situated in the valley of the river Big Zelenchuk $22 \mathrm{~km}$ to the south of stanitsa Zelenchukskaya near the village of Nizhniy Arkhyz. Many authors of pre-revolutionist period thought that there had been a big Christian city here, and the Naryshkins and A. S. Fedorovskiy supposed that there had been a Byzantine monastery in Nizhniy Arkhyz. [6] Academic V. F. Miller was the first to state that it was the center of the Alan metropolitanate, which was mentioned in byzantine documents [7]. V. A. Kuznetsov calls this medieval city "the outpost of the byzantine influence in the North Caucasus" [8].

In the spatial and planning structure of a hillfort we can see the territory of the city itself and the territory of the Alan metropolitanate outside its boundaries separated by a field. A similar separation of the city territory from the metropolitanate can be seen in the planning structure of Byzantine cities of VIII-IX c., for example Sardies. [9]. The main part of the structure of the city, including the fortifications, is situated in the plain part of the valley and, in what concerns composition, is defined by its configuration. The fortifications were built taking into account the peculiarities of the relief and cross the valley in cross direction, 
where it lacks natural fortifications, creating four lines of defense. In the territory of the hillfort there are 3 cross-domed churches and 11 mono-apsidal churches.

V. A. Kuznetsov dates the Nizhniy Arkhyz hillfort back to the X-XII c. In 1962 he made tow exploring shafts in the central part of the hillfort which revealed the cultural layer of the X-XII c. The height of the layer is 0,7-1 m. During his further researches he confirmed this dating. [10]

We need to notice that the planning structure of Nizhniy Arkhyz hillfort is different from that of traditional Alan hillforts, which had a three-part planning: a citadel, a fortress, a fortified settlement. Probably, it is due to the fact that that planning structure of Nizhniy Arkhyz hillfort was mainly influenced by the traditions of the Byzantine Christian topography.

Leso-Kyafarskoe hillfort is situated in Kyafarskoe ravine on mount Shpil near the junction of the river Kyafar and the river Krivaya three $\mathrm{km}$. south of the modern village Leso-Kyafar. In the planning structure of the Kyafarskoe hillfort we can see a three-part division typical of the most of Alan settlements: a citadel, a fortress, a fortified settlement. In the territory of the hillfort I. A. Arzhantseva registered more than 200 stone buildings which give enough information about the planning structure of the settlement. [11]

In the vicinity of Leso-Kyafarskoe hillfort V. A. Kuznetsov studied numerous aboveground sepulchers. He dates the collected inventory back to VIII-XIV c. and also marks the earliest burial site as belonging to the VIII-IX c [12]. "The summarized date of the tombs is considered to be the VIII-XII c. This date can be a reference point for the dating of Kyafarskoe hillfort because it is definitely linked to the described necropolis". [13]

According to the description by U. Y. Elkanov, Leso-Kyafarskoe hillfort is an elaborate archaeological complex, which can be dated back to the VI-XIV c. He bases his dating on the discovered examples of black-glazed ceramics and bronze mirror [14

H. H. Bidzhiev, basing on the researches by V. A. Kuznetsov and V. I. Markovin, dates Leso-Kyafarskoe hillfort back to the VIII-XIII c. [15]

Humarinskoe hillfort is situated on the right bank of the river Kuban $11 \mathrm{~km}$ to the north of the city of Karachaevsk, over the aul of Humar on an elevated plateau Kalezh with deep arroyos: Inal in the north and Shugara in the south. Humarinskoe hillfort was situated in the territory of medieval Alania, where was located the western Caucasian branch of the Great Silk Way. At the same time the cultural layer of Alan origin wasn't revealed in the hillfort. H. H. Bidzhiev and A. V. Gadlo think that it belonged to the Saltovo-Mayaki people - the main culture of the Khazar Khaganate. They base their conclusions on the ceramic material and the similarity between the building technique of this fortress and white-stone fortresses of north-western Khazaria (Pravoberezhnoe, Tsimlyanskoe, Mayatskoe hillforts). [16]

The planning structure of Humarinskoe hillfort has a three-part division: a citadel, a fortress and a fortified settlement. Among the fortifications we can see walls, towers, citadel buildings and earth moats. According to its dimensions and the efficiency of the fortifications Humarinskoe hillfort greatly surpasses all known hillforts of the SaltovoMayaki culture (brick Sarkel and Semikarakory, stone Mayatskoe, Verkhne-Olshanskoe and Verkhne-Saltovskoe). Compared to Humara they look tiny. [17] After the fall of the Khaganate people left the fortress. The Alan people of the region for some reasons didn't occupy the preserved hillfort with the first-class fortifications. [18]

As a result of multiyear excavations H. H. Bidzhiev managed to determine the stratigraphy of the monument, which, according to the archaeological material, can be divided into three historical eras: the VIII- VI c. B.C., the II-VII c A.D. and the VIII-X c. A.D. At the same time the cultural layers of the VIII-XI c B.C. and the II-VII c. A.D. are not traced everywhere and the cultural layer of the VIII-X c. A.D. is a proof of intense life in the hillfort during this period. [19] The question of the construction period of the walls if 
still open and we still don't know the location of the necropolis belonging to the people of Humarinskoe hillfort. [20]

M. S. Gadzhiev draws architectural and building parallels between the fortifications of Humarinskoe hillfort and early-medieval fortifications of Derbent and other fortresses in early-medieval Dagestan. M. S. Gadzhiev supposed that people of Iran probably built the fortifications of Humarinskoe hillfort in the territory of Alania in 560 A.D. It was done because for Iran it was necessary to have a garrison and control the strategically important branch of the Great Silk Way in the area. [21]

Karakentskoe hillfort is situated in the ravine of the Kuban in the south-west end of the aul of Kumysh, on the flat top of the cape, on the left bank of the Kuban opposite Humarinskoe hillfort. The hillfort has the three-part planning structure: a citadel, a fortress, a settlement. Along the perimeter of the cape the hillfort is protected with thick fortification walls and heavy towers. The citadel is in the eastern part of the cape and has its own fortification wall. The settlement adjoins the hillfort from the south-eastern part. H. H. Bidzhiev dates Karakentskoe hillfort back to VI-XII c. [22]

Indzhur-Gatinskoe hillfort is situated in the ravine of the Kuban on a small plateau 4 $\mathrm{km}$. away from the mouth of the river Indhzur-Gata, $20 \mathrm{~km}$. to the north of the city of Karachaevsk. In the eastern part of the hillfort there is a lift in the form of a hill $5 \mathrm{~m}$. higher than the ground. During the archaeological researches by T. M. Minaeva it was revealed that it is what remained from ancient buildings surrounded with walls along the perimeter. Maybe, the citadel of the hillfort was situated here. The wall from the hillfort side has an outline in the shape of a bow, other wall are straight. Near the embowed walls there was an examined Christian necropolis. T. M. Minaeva dates the hillfort back to the IX-XI c. This date is based on the elements of black-glazed ceramics typical of the Prikuban region and discovered during the excavations. [23]

Gilyachskoe hillfort was situated in the ravine of the Kuban on an offshoot mountain on the left bank of the river Gilyach 13 to the south of the city of Karachaevka. In the highest part pf the hillfort facing the ravine there were citadel buildings: two towers and fortification walls. On the western edge of the offshoot there was a Christian church with a staircase leading to it. On the western edge there are preserved elements of houses situated in steps. T. M. Minaeva dates this hillfort back to the VIII-XII c. [24]

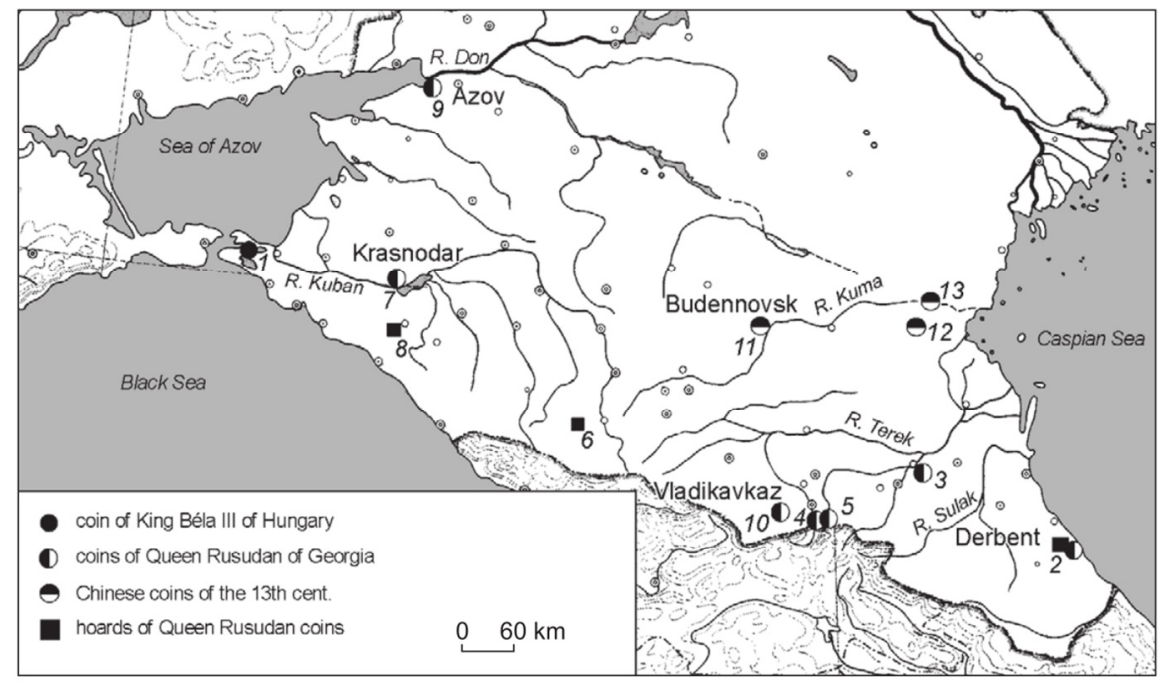

Fig.1. The occurrences of Eurasian coins of the 13th cent. in the Northern Caucasus.

Source: [25]. 
Adiukhskoe hillfort is situated in the ravine of the river M. Zelenchuk on a cape between the right bank of the M. Zelenchuk and the mouth of Adiukh hollow opposite the aul of Khabez. The archeological excavations of the hillfort were headed by T. M. Minaeva, who dates it back to the VII-XII c. In the cultural level there are two bedrocks: the lower - the VI-IX c. and the upper - the X-XII c. [25] The hillfort consists of three parts separated from one another with fortifications. In the first part there was a settlement and later - a Christian church. During the excavations there was found a cross-encolpion of the XI-XII c. In the same place there was a Christian sepulcher. The first part of the hillfort was separated from the second part with a stone wall and a $6 \mathrm{~m}$. deep moat. In the second part the researchers discovered the structures connected with the pre Christian cult activity of the V-VI c.: a vertical stone in the center of a circle carved in primary rock; a burial place of the head and the legs of a horse; a hearth made of stone. In VII-X c. the second part was built-up. In X-XII c. between the second and the third parts they built a fortification wall and dug a moat. [26] The third part of the hillfort was separated from the continent with two fortification walls. The houses situated near the first wall in the third part of the hillfort are dated back to the VIII-IX basing on the elements of ceramics discovered there. [27]

Amgatinskoe hillfort is situated in the ravine of Teberda in the upper ground of mountain uplift. It is situated on three offshoots which form the top of the uplift. The hillfort is situated in a hard to reach place and has thick fortifications presented by walls along the perimeter of each offshoot. The northern offshoot the most fortified. Along the perimeter it is covered with two, sometimes three, fortification walls. In the territory of the northern offshoot there was a Christian temple, dated back to XI-XII century by V. A. Kuzentsov. The necropolis of Amgatiskoe hillfort is dated back to IV-VII c A.D. by H. H. Budzhiev He also created the preliminary timeframe for the hillfort - IV-XIII c. [28] A more exact dating can be given during the further researches of the monument.

In summary, we can draw the following conclusions. The time of the creation and existence of western Alan hillforts chronologically corresponds to three important historical events: the creation of the Western-Caucasian branch of the Great Silk Way, which in the VI c. A.D. lead through the territory of Western Alania; the consolidation of the Khazar Khaganate in the North Caucasus in VIII c.; the growth of the byzantine influence in the west of Alania and the spread of Christianity in X c. According to archaeological data, most hillforts in Western Alania have all the three periods in their stratigraphy. So we can mark three chronological periods of the development of the architecture of Western Alania: the VI-VII c. A.D., the VIII- the first half of X c. A.D. and the X-XII c. A.D.

At the first stage, in VI-XII c. appeared the first Alan settlements in the westernCaucasian part of the Great Silk Way. At the second stage, in VIII- the first half of X c. in hillforts appear fortifications and shapes the three-part planning scheme: a citadel, a fortress, a fortified settlement. At the third stage, in the X-XII c. the hillforts developed under the influence of the traditions of byzantine Christian topography. In the townplanning composition appear image-bearing and symbolic dominant elements such as Christian temples and churches, which were the centers of ribbon building and shaped the routes. The location of the temples corresponds to the byzantine Christian canons, the main streets lead to these temples, defining the architectural and spatial carcass of the settlement.

The research is supported by grant RFBR №_19-012-00402

\section{References}

1. H. H. Bidzhiev, Humarinskoe gorodishche (Cherkessk, 1983).

2. V. A. Kuznetsov, Alanskie plemena Severnogo Kavkaza (Akademiya Nauk SSSR, Moscow, 1962). 
3. V. A. Kuznetsov, Zodchestvo feodalnoy Alanii (Ordzhonikidze, 1977).

4. G. V. Esaulov, Arkhitektura Uga Rossii. Etapy istorii, Arkhitekton, 3-4, 67-71 (Ekaterinburg, 1998).

5. M. S. Gadzhiev, Khumara: nekotorye stroitelnye paralleli I problema datirovki ukrepleniy. Ocherki srednevekovoy arkheologii Kavkaza, K 85-letiyu so dnya rozhdeniya V. A. Kuznetsova 51-65 (2013).

6. Naryshkiny, Otchet gospod Naryshkinyh, sovershivshih puteshestvie na Kavkaz (Svanetiyu) c arkheologicheskoy tseliyu $v 1867 \mathrm{~g}$, Izvestiya Russkogo Arkheologicheskogo obshchestva, 8, 325-368 (1877).

7. N. F. Miller, Drevneosetinskiy pamyatnik iz Kubanskoy oblasti, Materialy po arkheologii Kavkaza, III, 110-118 (1893).

8. V. A. Kuznetsov, Nizhniy Arkhyz $d X-X X$ vv. $K$ istorii srednevekovyh gorodov Severnogo Kavkaza (Stavrolol', 1993).

9. G. L. Kurbatov, G. E. Lebedeva, Gorod I gosudarstvo v drevnih obshchestvah, (Leningrad, 1982).

10. V. A. Kuznetsov, Raskopki alanskih gorodov Severnogo Kavkaza v 1962 g, Kratkiye Soobshcheniya Instituta arkheologii Akademii nauk SSSR, 98, 107-115 (1964).

11. I. A. Arzhantseva, Alanskoye gorodishche Kyafar IX-XII vv. n.e. v Karachaye, Karachayevtsy y balkartsy: yazyk, etnographia, arkheologiya, folklore, (Moscow, 2001).

12. V. A. Kuznetsov, Nazemnye grobnitsy na r. Krivoy v Stavropolskom kraye, Kratkiye soobshcheniya Instituta istorii materialnoy kultury RAN, 76, 83-89 (1959).

13. V. A. Kuznetsov, Durgulel' Velikiy I Nizhniy Arkhyz, Metodika issledovaniya I interpretatsii arkheologicheskih materialov Severnogo Kavkaza (Ordzhonikidze, 1988).

14. U. Y. Elkanov, I slyshny otzvuki vekov (Leninskoye znamya, 1986).

15. H. H. Bidzhiev, Issledovaniye srednevekovyh poseleniy Karachaevo-Cherkessii I stepnogo Predkavkazya v 1985-1986 gg., Voprosy arkheologii I srednevekovoi istorii Karachaevo-cherkessii (Cherkessk, 1989).

16. H. H. Bidzhiev, A. V. Gadlo, Issledovaniya 1874 g. na Humarinskom gorodishche v Karachaevo-Cherkessii, Materialy po izucheniyu kulturnogo naslediya Severnogo Kavkaza, VIII. Krupnovskiye chteniya 1971-2006, M., 2008, pp. 121-122

17. V. S. Flerov, "Goroda" I "Zamli" Khazarskogo Kaganata, Arkheologicheskaya realnost' (2010).

18. U. Y. Kochkarov, Ukreplennye poseleniya Khazarskogo kaganata, Vestnik Rossiyskogo gumanitarnogo nauchnogo fonda, 2 (67), 59-70 (2012).

19. M. S. Gadzhiev, Humara: nekotorye stroitelnye paralleli I problema datirovki ukrepleniy, Ocherki srednevekovoy arkgeologii Kavkaza K 85-letiu so dnya rozhdeniya V. A. Kuznetsova (Moscow, 2013).

20. T. M. Minaeva, $K$ istorii alan Verkhnego Prikubanya po arkheologicheskim dannym (Stavropol', 1971).

21. T. M. Minaeva, Otchet o raskopkah gorodishcha Gilyach v 1961 g, Arkhiv IA RAN, F. R-1 D. № 2438 (Moscow, 1962).

22. T. M. Minaeva, Gorodishche na balke Adiukh v Cherkessii, Sbornik Nauchnyh trudov Stavropolskogo Gosudarstvennogo pedagogicheskogog intituta, 9, 129-161 (1955). 
23. E. P. Alekseeva, Arkheologicheskie pamyatniki Karachaevo-Cherkessii (Mosocw, 1992).

24. T. M. Minaeva, Otchet o raskopkah gorodishcha Adiukh v 1960 g., Arkhiv IA RAN, F. R-1 № 2229, (Moscow, 1961).

25. E. I. Narozhny, F. B. Narozhnaya,. Archaeology, Ethnology and Anthropology of Eurasia 37(1), 52-61 (2009). 